\title{
Modernisation or Workfare? New Labour's Work-Based Welfare State
}

\author{
Dan Finn, Reader in Social Policy, University of Portsmouth
}

\section{Welfare to Work}

Fundamental changes in the nature of and availability of employment have intensified the pressures being experienced by welfare systems throughout the OECD. In particular, it is suggested that long term unemployment and social exclusion are being exacerbated by changes in the character and availability of 'entry level' jobs and by the passive nature of traditional social assistance and unemployment compensation systems.

In response to the OECD's 'Jobs Strategy' (1994) and the EU's 'Employment Pact' Government's are modernising the relationship between their benefit systems and labour markets. New and tougher work tests have been introduced, especially for the unemployed, and these are linked with voluntary or mandatory attendance at a diverse range of job search, employment and training programmes. In what the Director General of DGV hailed as a "decisive shift away from passive to active measures” EU Member States have committed themselves to providing a 'New Start' for all those under 25 unemployed for six months and for those over 25 after a year out of work (Laarson, 1998, p.6).

The shared aim of what could now be described as these 'welfare to work' regimes is to increase economic activity rates through the creation of 'active' benefit systems which improve employability, reinforce work incentives and reduce costs and welfare dependency. Significantly, the new regimes are increasingly being aimed at all those of working age, partly because of falling unemployment but also because the growth in fiscal costs has been linked directly with increased numbers of economically 'inactive' lone parents and people on disability benefits (who once inside the benefit system tend to rely on their welfare payments for much longer periods than the registered unemployed).

At the heart of this modernisation of welfare states has been a continuing attempt to define and create a new type of social contract between the individual and the state. Whether it be the 'reciprocal' or 'mutual' obligation of Australia; the transition from 'sharing' to 'earning' of the Netherlands; or the 'helping hand' rather than 'handout' rhetoric of the USA and UK, active job search and employment requirements are being intensified for all working age people who rely on social assistance payments. For some this represents a welcome modernisation of the post war welfare state (Milliband, 1999). It involves creating a system 'in tune' with modern social and labour market realities with a decisive shift from simple 'benefit handouts', which failed to tackle exclusion, towards services which enable and incentivise individuals to become more self sufficient. For others, by contrast, it represents the transition from the Keynsian welfare state to an Orwellian sounding "Schumpterian workfare state" where more or less coercive benefit regimes are aimed at re-integrating the unemployed "into a post-Fordist labour process" (Jessop, 1994, p. 32; Peck and Jones, 1995; Tonge, 1999). 
Whatever the theoretical position taken it is clear that welfare to work strategies are not just about the abstract redefinition of rights and responsibilities, or the creation of new opportunities, incentives and sanctions. Governments have coupled changed policy objectives with organisational reform and have linked the transition to active benefit regimes with radical changes in the bureaucracies delivering and administering programmes. New post-Fordist institutions are emerging where monolithic national service agencies are now being required to work in local partnerships and public sector monopolies, in the delivery of employment and training services, are being dismantled to be replaced by quasi-markets (Finn, 2000; de Koning et al, 1999; Le Grand and Bartlett, 1993). These organisational reforms are linked with the introduction of new management techniques and a new generation of front line employment advisers or case managers who have the task of turning abstract incentives, opportunities and sanctions into real day to day choices.

\section{New Labour and Welfare to Work}

The New Labour Government has put itself at the forefront of this international process of 'welfare reform'. Shortly after his electoral victory the British Prime Minister suggested that the "greatest challenge" for his "welfare to work" Government was "to refashion our institutions to bring the new workless class back into society and into useful work" (PM, 1997, p. 4). The objectives of this transformation are both economic and cultural. One aim is to increase the sustainable level of employment by improving the employability of more benefit claimants and placing them into work. The other is to change the culture of the benefits system towards independence and work rather than payments and dependence (HMSO, 1999, Chapter 4).

The following sections describe and assess the key changes that have been introduced, involving the introduction and rapid extension of a variety of New Deal programmes; the role of the public Employment Service (ES); the delivery of these programmes through local partnerships and a new generation of 'front line' New Deal personal advisers; tax and benefit reform to 'make work pay'; and the 'activation' of the benefit system, where lone parents, carers and people receiving disability benefits, can now be required to attend work related interviews and assessments.

\section{The New Deals and Attendance Requirements}

The Labour Government's New Deals are made up of a complex mix of mandatory and voluntary job search advice, employment and training programmes. The overall objectives of the various New Deals are:

- to increase long term employability and help young and long-term unemployed people, lone parents and disabled people into jobs; and

- improve their prospects of staying and progressing in employment. 
Participation in the New Deals for the registered unemployed usually commences with an intensive advisory 'Gateway' process aimed at helping an individual find work, followed by a more or less resource intensive range of employment and training options which aim to improve individual employability. There is a 'follow through' process of advice and support for those who do not get a job by the time they complete their option. Young people under 25 years of age enter the New Deal after six months unemployment, those over 25 enter after 18 months. Participation is compulsory for those aged under 50 .

The Labour Government has emphasised that the New Deals for the unemployed represent a new balance of 'rights and responsibilities' within which there is "no .. option of an inactive life on benefit” (PM, 1997, p. 7). In practice the disciplinary regime of the New Deal builds on the regulations introduced in 1996 following the introduction of the Jobseekers Allowance. These JSA rules stipulate that to be eligible for benefit unemployed individuals must enter a Jobseekers Agreement specifying the steps they intend to take to look for work. Disallowance or sanctions of varying severity can be imposed on those who refuse 'suitable' employment, fail to actively seek work, or who become unavailable for work. Officials also have a discretionary power enabling them to issue a 'Jobseekers Direction' requiring an individual to look for work in a particular way or to take other steps to 'improve their employability'.

In practice most unemployed people have participated voluntarily in the New Deal but by 2000 the numbers who had experienced 'mandatory referrals' and/or sanctions was increasing. Those who refused to take up places or who left them early, without 'good cause' (such as, health reasons, unreasonable travelling time, etc.), faced escalating sanctions. Initially they could be subject to a two week benefit sanction, a second refusal would result in a four week sanction, and a third refusal would result in a loss of benefit for up to six months (Chatrick and Convery, 2000)

New Deals have also been created for working age people living on state benefits who were previously regarded as 'economically inactive'. For example, from 2000 the wives or dependent partners of those unemployed people who are eligible for the young person's New Deal, and who do not have child care responsibilities, have been required to register and regularly sign on as unemployed and participate in ES programmes and, when eligible, enter what is called the 'New Deal for Partners'. Initially this new requirement applies only to small numbers of 18 to 24 year old partners but the intention is to gradually extend this approach to the older age groups. In a context where both partners in most British families of working age now have jobs the aim is to end the assumption of 'spouse dependency' in the benefit system.

There are also voluntary New Deal programmes for lone parents and for people with disabilities. Lone parents who make their first claim for state benefits or whose youngest child starts school are given advice, directed as to where they might get jobs or upgrade their skills and advised about any child-care support that can be obtained. The programme for people with disabilities has been less prescriptive, and through a broad range of pilot programmes organisations working with the target group are testing new advisory services, and a limited range of more intensive support, aimed at enabling people claiming disability benefits to return to work. 
Although these programmes remain voluntary they now operate in a regulatory regime where lone parents and other working age people applying for and receiving state benefits are required to attend employment related interviews. From April 2001 all lone parents who want to claim income support have to attend an interview where their circumstances are reviewed and where an adviser will assess their employability and give advice about how they could move towards self sufficiency. These and existing lone parents will thereafter be expected to attend reviews at least annually.

In twelve 'One' pilot areas (see below) this approach is being tested across the full range of benefit recipients and people who claim disability benefits, carers benefits, and so on, are also required to attend employment related interviews. The policy objective has both an enabling and policing element but the Government has stressed the positive gains for individuals and have made it clear "that no-one should feel intimidated" and "invitations to participate should be encouraging rather than threatening” (ESC and SSC, 1999, p. ix). There are also a variety of deferrals and exemptions and apart from the JSA unemployed other individuals cannot be legally required to participate in a programme or take a job.

The Government has supplemented its national New Deal programmes and 'activation' of the benefit system with area based employment initiatives targeted at those localities which have the highest levels of long term unemployment and 'joblessness'. In 15 'fully fledged' Employment Zones the Government is testing out the concept of 'benefit transfer' where contracted providers are able to combine the resources that were available both for benefits, training and job search into a 'personal job account' which can then be used flexibly to obtain the most appropriate support (initially for up to 48,000 of the long term unemployed). In 20 areas new 'Action Teams' are also being tested, initially for a year (DfEE, 2000a). The teams are expected to work with all 'jobless' people to "support radical, innovative ways" of tackling "specific local problems and obstacles to jobmatching". They are voluntary, work with all those who want jobs, and their effectiveness will be assessed through the improvement they can make in local employment rates. These area based initiatives are expected to build 'synergy' between their activities, the New Deals and the regeneration programmes being supported through other Government interventions, such as the 'New Deal for Communities' and the Single Regeneration Budget.

\section{'Making Work Pay' and the New Deals}

All the above programmes have been introduced alongside major tax reforms which, in combination with new rights at work, are aimed at 'making work pay'. In a variety of ways unemployment and 'poverty traps' have been significantly eased as part of a major redistribution of resources towards poor working families and children (estimated to lift around 840,000 children out of poverty in the first Parliament of the Labour Government: Piachaud and Sutherland, 2000). It is not proposed to assess these policies in detail in this article, but the impact of the various tax and child care credits alone mean that by 2000 the Government was able to guarantee that a family 
with a full-time worker would have a minimum income of over $£ 10,000$ a year and would have $70 \%$ of their child care costs met by the state (Hirsch, 2000, p. 36).

In effect, through the New Deals and 'making work pay' the Labour Government is integrating the active benefit regime it inherited into the broader process of welfare reform through which it intends to "rebuild the welfare state around work". In this new era "it is the Government's responsibility to promote work opportunities" and "the responsibility of those who can take them up to do so" (HMSO, 1998a, p 23 \& 31). The critical assumption is that welfare dependency and unemployment can be substantially reduced by both improving the employability of working age benefit recipients and by connecting them more proactively to the labour market.

\section{Delivering the 'work-based welfare state': the Employment Service, Partnerships, the 'One' service and the Working Age Agency}

Within weeks of taking office the Labour Government gave the ES the lead responsibility for delivering the New Deal. The senior managers of the agency grasped the opportunity to 'reinvent' the organisation and invested substantial time and resources in redefining its approach in order to rebuild its credibility with the unemployed, employers and other agencies. This involved the creation of a national network of local New Deal partnerships; the introduction of a new generation of front line personal advisers; contracting with a broad range of public, voluntary and private sector organisations for the delivery of new services and employment and training options; and changes to its performance targets which have started to encourage it to work with other agencies.

Another key dimension to the strategy has involved a major political effort to engage employers and other agencies in the delivery of the New Deals. In particular Government has created a broad range of national and local partnerships, from the advisory national New Deal Task Force through to the contractual partnerships which deliver particular programmes. For New Labour 'partnerships' are now seen as the alternative to simplistic free market solutions and the "old centralised command and control systems, which stifled innovation”. The 'third way', favoured by the Prime Minister, involves creating "partnerships at local level, with investment tied to targets and measured outcomes, with national standards but local freedom to manage and innovate” (Blair, 1998, p. 15).

Partnership working was an essential characteristic of the Government's policy for testing a range of pilot approaches to creating what the Prime Minister originally announced as a 'single work focussed gateway' to the benefit system (at the 1998 Labour Party Conference). What subsequently became described as 'One' pilots were to test how to integrate the delivery of, and create an employment focus to, the previously separate benefits claimed through the ES, the Benefits Agency and Local Authorities. The 'One’ service has three key objectives (HMSO, 1998b):

- $\quad$ to increase the sustainable level of employment by getting more benefit claimants into work by putting them in touch with the labour market through the intervention of a personal adviser; 
- to ensure that individuals experience customer service that is efficient and tailored to their personal needs; and

- to change the culture of the benefits system and the general public towards independence and work rather than payments and dependence.

Soon after the pilot programmes were introduced the Government announced the creation of a new unified 'working age agency', with a clear focus on employment, which will bring together the ES and those parts of the Benefits Agency which support people of working age (Local Authorities are expected to continue to administer Housing Benefit). The new service will learn from the existing 'One' pilots and deliver a single, integrated service to all working age benefit claimants and employers. After bringing together central functions in 2001 the new front end delivery of services will be gradually rolled out across the country. ${ }^{1}$ According to the Prime Minister the new agency will be in the front line of the drive to modernise Government and will continue to develop the partnership approach to working with local authorities and the private and voluntary sectors that has characterised the implementation of New Labour's welfare to work policies (Hansard, 16 March 2000, col. 257W).

In fact, recent developments in labour market policy have witnessed an expansion of direct private sector involvement in the delivery of new services for the unemployed (as part of a broader redefinition of the relationship between the ES and the private recruitment industry). Private sector organisations, in varying combinations with the ES, are now responsible for delivering most Employment Zones, and in a number of areas are delivering the New Deals for the unemployed and the One Service. Although there are continuities with the market testing and drive to privatisation of the previous Conservative administration the Government maintains that its approach does not represent a prelude to full privatisation but a variation of its partnership strategy. The stated aim is to create new public private partnerships that harness the resources, expertise and innovative practices of the private sector to the delivery of the broad welfare to work agenda.

Although initial critiques of Britain's New Deals highlighted a lack of geographical and programme flexibility (Turok and Webster, 1998; Peck, 1999), the impact of practice and subsequent policy changes mean that in most localities significant variations are now emerging. In particular, different types of local New Deal partnerships have been given flexibilities in how they deliver, and increasingly sequence, their programmes and build synergy with other provision (whether funded through the European Social Fund, the Single Regeneration Budget, and so on). At the same time there is virtually no part of the country which is not participating in one or other of the various pilots, trials, employment zones, prototypes, or innovative projects which have been introduced for different groups amongst the long term

\footnotetext{
${ }^{1}$ The Welfare to Work strategy and New Deal programmes apply throughout the UK but the ES and BA only cover GB. Devolution, and different institutional arrangements in Northern Ireland, will have some impact on policy and local delivery but the content and direction of welfare reform is firmly controlled by central UK Government.
} 
jobless. As a result, it is becoming increasingly hard to distinguish the core programmes from the mass of variants. And the huge mixed-economy of private, public and voluntary sector organisations that are delivering these initiatives is consequently going through a remarkable period of evolution and invention. This delivery system is also experiencing intense pressure with significant variations beginning to emerge in local performance and coherence.

\section{Participation in the New Deals}

By the end of July 2000, over two years after its national introduction, over half a million young unemployed people had started on the New Deal of whom 116,100 were still in the programme. Of these just over half were still in the initial Gateway stage and a third were in one of the options. Just under one in five of those on the options were in subsidised jobs, over $40 \%$ were on placements in environmental projects or in the voluntary sector, and just under $40 \%$ were in full time education or training. Nearly one in five of all those still on the New Deal were in the 'follow through' period back in unemployment although the ES was expected to continue to try to place them in jobs. Over $70 \%$ of participants were male, about $12 \%$ reported having a disability or work-related health problem, and $14 \%$ were from ethnic minority groups (DfEE, 2000b).

Of the 402,600 young people who were no longer in the programme 159,200 or $40 \%$ had been placed in unsubsidised jobs; 46,200 or $11 \%$ had started to claim other benefits; 78,600 or $20 \%$ had entered other known destinations (for example, full time education); and the destination of 118,500 or nearly $30 \%$ was unknown (ibid, Table 11). Data on retention showed that over 56,000 of those who were placed in jobs had left them within 13 weeks. The impact of this 'turnover' has been significant and the implications of what has been described as the 'revolving door' will be discussed in a later section.

During the first year of the New Deal for young people particular concern had been expressed about the large number of leavers whose destinations were unknown. However, follow up research with a sample of this group found that $57 \%$ of those contacted had actually left to take up a job, though only $29 \%$ were in work at the time of interview. Another $25 \%$ had left because of illness or caring responsibilities, and another $12 \%$ were no longer looking for work (NCSR, 1999). The Government concluded that these findings did not suggest that significant numbers of these young people were at risk of exclusion. Instead they indicated that some young people were only tentatively engaged with the labour market and were likely to move in and out of jobs quickly and take intermittent advantage of the help and support offered by the New Deal and other programmes.

The New Deal for those aged over 25 was initially restricted to those who had been out of work for over two years but eligibility was reduced to 18 months in April 2001 and extra resources were put into the programme to intensify the level of support and variety of options. By July 2000, two years after the original programme started, there had been 286,900 starts, of whom 74,500 were still in the New Deal. Most of those who were participating in the programme were still in the three to six month advisory 
period (77\%), with the others moving into subsidised jobs (7\%), work based training $(12 \%)$, or other full time education or training (2\%).Of those who had left the New Deal nearly 29,900 had gone into unsubsidised jobs; 24,100 had started to claim other benefits and 107,200 had returned to claim Jobseekers Allowance; 9,200 had entered other known destinations; and the destination of 21,200 ex-participants was unknown.

Results from the New Deal for Lone Parents reflected its voluntary nature, with about $20 \%$ of those who were asked to attend an initial interview taking up the offer.

Between October 1998 and July 2000 174,420 lone parents attended a first interview, with just under $90 \%$ agreeing to participate further. Of those who participated 57,530 had found jobs and 14,880 had taken up education or training opportunities. Of those involved $95 \%$ were women, $7 \%$ were from minority ethnic groups, $3 \%$ had disabilities, and 22\% were aged under 25 (DfEE, 2000c). An evaluation of the first NDLP pilots, which made detailed comparisons with matched areas without the new service, found that overall the net gains from programme paid for its costs, with "a substantial gain for both individual lone parents and for the economy as a whole" (Hasluck et al, 2000)

\section{New Deal Evaluation Evidence}

The overall labour market impact of the New Deal for the young unemployed - the 'flagship' of the programme - has been hotly contested (see below). However, the initial findings from the many case study and other evaluations point to some significant progress (Hasluck, 2000a; Hasluck 2000b; Millar, 2000; R\&DDES, 2000):

- The Gateway period of intensive advice and assistance has been effective in moving young people out of unemployment. Early planning assumptions were that $40 \%$ of entrants would leave the New Deal from the Gateway. In reality 58\% of participants leave before taking up an option. If those who are getting jobs in the 'unknown destinations' category are included, over 60\% of these young people are getting jobs.

- Participation on the Gateway leads to more intensive jobsearch. The evidence shows a 'carrot and stick' effect, with most intensifying jobsearch as a result of increased motivation and new techniques, but others doing so in order to avoid joining an option or to avoid benefit sanctions.

- New Deal Personal Advisers are playing a critical role. The evaluation evidence has consistently identified the intensive, individualised help from the adviser as the key element of Gateway success. Young people themselves place great value on having someone with whom they can build a relationship. Advisers provide a wide range of individualised services for the young person such as identifying barriers to work, helping with applications, contacting employers and discussing and clarifying employment goals. In addition to the options they can also provide access to additional services, ranging from referrals to substance abuse programmes to help with literacy and numeracy.

- 'Continuous Improvement' and the Gateway. As problems have emerged, for example, around identifying basic skills problems or the lack of intensity of 
contact, the Gateway has been changed to better tackle the emerging issues, albeit the success in some areas has been limited.

- The performance of the options has been mixed. As a result of the impact of the Gateway less than $40 \%$ of entrants have progressed to options, as against the $60 \%$ originally anticipated. This means that those entering the options are those with the greatest barriers to employment. This partly explains why the job subsidy element of the New Deal has had less take up than anticipated and employers have been critical of the quality of the young people referred. Nevertheless most of the young people in subsidised employment have either been retained by their employer or have been able to get other jobs. By contrast, the job entry performance of the other options has been weak, with no more than $15 \%$ of participants progressing directly into employment.

- The follow through period appears to be succeeding in capitalising on the increase in employability created through Gateway and option participation, with around $40 \%$ of leavers from follow through moving into employment.

Despite this progress there is evidence that the implementation architecture of the New Deal is under considerable pressure, especially in high unemployment inner city areas where performance is poorest. Early evidence from reviews conducted by the New Deal Task Force and from unpublished research in Manchester, Portsmouth and other cities, has found front line New Deal advisers expressing:

- concern that the individual focus of New Deal has given way to increased emphasis on placements, especially into unsubsidised jobs, driven by targets;

- frustration at frequent changes in complex procedures and processes;

- the burden of excessive paperwork;

- the demands of caseloads made up of clients with more intractable problems who have to be seen regularly; and

- frustration with the sanctions regime and the difficulty of tackling those thought to be (ab)using the system

It has been suggested that a classic 'implementation gap' - first described in Lipsky's seminal study of 'street level bureaucrats' - has emerged as the New Deal has been made a day to day reality (Lipsky, 1980; Blackmore, 1999). Lipsky found that front line officials were often overwhelmed by the competing demands of their jobs and often used the discretion they enjoyed to develop survival mechanisms which could reinterpret, deflect and even undermine public policy objectives. There is already evidence that the impact of the last Conservative Government's actively seeking work test and 'stricter benefit regime' were vitiated through such an implementation gap, and it may be that at least in some areas the front line reality of the New Deal may be very different to that which the policy rhetoric suggests (Bryson and Jacobs, 1992; McKay et al, 1997; Finn, et al, 1998). In particular, one significant dimension of this gap between rhetoric and reality is that established forms of regulation and contestability are being redefined, if not undermined. 'Clients' and welfare rights organisations now confront an increasingly opaque system characterised by diversity, flexibility, increased front line discretion, and an emphasis on 'appropriate' behaviour (Ramia and Carney, 1999). 


\section{The Labour Market Impact of the New Deal}

Essentially, there are two propositions that underpin the Labour Governments welfare to work strategy. The first is that a more active benefit regime and New Deal programmes will help reduce unemployment and wage pressures, stimulate the economy and lead eventually to more jobs. The second assumption is that on an individual level the new approach will improve the employability and/or earning capacity of people currently living on benefits.

In terms of the direct impact of the New Deals on unemployment by February 2000 the number of 18 to 24 year olds unemployed who had been claiming JSA for over six months had fallen to just over 52,000. This compared with 169,500 in May 1997, when the New Labour Government was elected. The fall in the number unemployed for over a year was even more dramatic, from 85,500 to 6,100 . Using the more rigorous international (ILO) definition of unemployment, on data collected from the Labour Force Survey (which includes those who are unemployed but not eligible for JSA) the number of young people unemployed over six months had fallen to 123,000 in the March-May 2000 quarter from 221,000 in the February-April 1997 quarter (ONS, 2000, Tables 11 \& 9). The sustained fall in long term unemployment has been less marked for the older age groups but the long term rate has still fallen faster than the general unemployment rate (in contrast with earlier economic recoveries when long term unemployment has been a 'lagging' indicator).

Although the fall in long term unemployment durations has been significant the question is how much of this impact has been due to the New Deals. The early results from more rigorous labour market evaluations of the New Deal indicate that the programme was creating an additional 'net' labour market effect (Layard, 2000). A report from the National Institute of Social and Economic Research estimated that in its first year the New Deal for Young People had reduced youth unemployment, relative to what it would otherwise have been, by 30,000: equivalent to a reduction in long term youth unemployment of nearly $40 \%$. This did not appear to be at the expense of other unemployed people. The report also suggested that while the overall future net impact of the programme on the economy was likely to be small, the programme would be self financing as the extra economic activity it generated would lead to higher Government revenues (Anderton et al, 2000).

An update of the research, more than two years into the programme, confirmed these findings (R\&DDES, 2000, p. 1). The overall level of youth unemployment was estimated to be 44,000 lower than it would have been and employment was 15,000 higher. There were additional impacts on the overall labour market, with "overall employment thought to be around 30,000 higher" than it would have been without the programme. Within two years it was suggested that these impacts had largely offset the cost of the programme.

In both reports, the authors acknowledged that their findings were tentative and the programme and research was still at an early stage. Others were more critical, suggesting that the findings were 'guestimates' producing the results the Government 
would wish to see. The Conservative opposition has since regularly attacked the various New Deals, dismissing them as expensive failures, and indicating that if they are returned to power the New Deals will be terminated.

The international evidence about the overall impact of New Deal type programmes is equivocal. An OECD review found that the relevant literature is bedevilled by complex data and technical difficulties, and the results are inconclusive, with "some studies appearing to show robust effects of active policies in terms of lowering the natural rate of unemployment or real wage pressures, others appearing to show zero or insignificant correlations" (Martin, 1998, p. 13). The author concludes that so far "the jury is still out”.

Although there may be no consensus around the macro economic proposition, many economists and policy makers accept that there is still a strong case for investment in labour market programmes, on the grounds of equity, social cohesion and efficiency. In this context, British programme evaluation evidence has more positive implications for the change of direction represented in the New Deals.

Control group and qualitative local studies show that the net impact of programmes on individual job prospects can be significant, especially where they are more effectively customised to individual and local labour market needs. Higher quality evaluations, using sophisticated comparison techniques, illustrate that earlier programmes which contain elements of the New Deal approach, especially those either directly linked with real employers or offering training, had an impact on employment prospects and earnings over quite long periods (see, for example, Payne et al, 1996; White et al, 1997). However, as White and his colleagues emphasised, the best results were found with programmes that were "selective, small scale and resource intensive" and they warned that if they were expanded in a simple way this could reduce their success rate (1997, p.37). A vital challenge for the New Deals, and the related area based initiatives, will be their capacity, through the local delivery mechanisms that have been established, to build on the positive impact and potential that these earlier programmes have demonstrated is possible.

A more challenging issue, however, involves tackling what has been described as the 'revolving door', where as many as $20 \%$ of those now joining the New Deal have participated in the programme at least once already. For many critics this 'revolving door' and what are described as 'jobs gaps' remain the fundamental weaknesses of the 'supply side' policies represented by the New Deal (Turok \& Webster, 1998; Peck, 1999).

\section{The 'revolving door': the 'Job Retention' and 'Jobs Gap' challenges}

In common with many other countries, the UK labour market has experienced a transformation as employer demand has continued to shift away from the traditional jobs taken by male, full-time manual workers. By 1995/96, for example, while more than $55 \%$ of all job takers in the UK entered full time permanent jobs, only $22 \%$ of the jobs taken by those out of work were full time and permanent; two thirds were part time or temporary. Most of the new jobs were relatively low paid and were 
predominantly in personal services, sales and other low skilled sectors (Gregg and Wadsworth, 1997, p. 24). Although the good news for some was that the entry job could become a route to a better job, either with the same or another employer, for many it was a 'revolving door' which led to a quick return to unemployment. In the same year over half the people who stopped claiming unemployment benefit were to become unemployed again within a year, and over $80 \%$ of those who completed Government training schemes also returned to unemployment (LMT, 1996). These labour market realities were particularly acute in many of Britain's older cities (Turok and Edge, 1999).

Although control group evaluations show that the better designed and resourced programmes of the late 1980s and early 1990s had a significant net impact on job prospects, and that those who participated in work based training were more likely to obtain secure and better paid work, the evidence also showed that large numbers of participants in even the best programmes were likely to return to unemployment. This 'revolving door' effect may reflect labour market realities but it did great damage to the credibility of training and employment programmes and managing and minimising its impact will be one of the major tests of Labour's New Deals. In this context, particular emphasis is now being placed on improving job 'retention' strategies, to ensure that New Deal participants keep the jobs they enter; on the 'follow through', to get effective assistance to those who come to the end of their placements without a job; and to 'progression', where skill training and follow up support can assist those who do take entry level jobs to be able to make progress to higher paid and more secure employment (NDTF, 1999).

Critics are still dismissive. Even if policy can influence retention and progression they suggest that there are structural 'jobs gaps', especially in Britain's cities, and that "it is a supply-side fallacy to suggest that improving employability will increase the aggregate level of labour demand" (Peck and Theodore, 1999, p. 14; Turok and Edge, 1999). Many high unemployment areas are failing to benefit equally from overall jobs growth and falling unemployment and it is argued that in these areas the New Deals could begin to look very much like the failed programmes of the past. Without jobs to go to the programme could simply waste resources and merely churn "people into and out of temporary projects and work placements, with no lasting reduction in unemployment” (Turock and Webster, 1998, p.325).

Government Ministers have resisted calls to expand public sector employment in these areas. They point out that large numbers of the long term unemployed live close to areas which have job vacancies, especially in London, and that the New Deal is aimed at tackling the attitudinal, cultural and physical barriers that prevent them from competing for those jobs. They also point out that in those areas undergoing structural economic change there are other programmes aimed at regenerating their local economies. With overall registered unemployment at its lowest level for over twenty years, and with record numbers of people in work, Ministers and their advisers have now indicated that full employment is realisable and have claimed that the New Deals and other welfare to work initiatives had already started to have a positive impact on the operation of the labour market (Layard, 2000). 
The reality is that both arguments are overstated. The evidence so far indicates that as Britain modernises its welfare state the New Deals are helping to secure significant if modest improvements in the employability and job prospects of those living on benefit, especially for the younger unemployed. However, there are still major challenges, in the high unemployment inner city areas in particular, where closing the 'revolving door' and translating worthy policy objectives and theoretical design into effective day to day practice are likely to require something more substantial than Labour's New Deals. 


\section{References}

Anderton B., Riley R. and Young G. (2000) New Deal for Young People: First Year Analysis of Implications for the Macroeconomy, ESR 33, Employment Service Research and Development Branch, Sheffield.

Blair, T. (1998) The Third Way: New Politics for the New Century, Pamphlet No. 588. Fabian Society, London.

Blackmore M. (1999) Mind the Gap: exploring the implementation deficit in the administration of the Stricter Benefits Regime, paper presented at the $32^{\text {nd }}$ Social Policy Association Conference, 20-22 July, Roehampton Institute, London.

Bryson, A. and Jacobs, J. (1992) Policing the Workshy: Benefit Controls, the Labour Market and the Unemployed, Avebury, Hampshire.

Chatrick B. and Convery P. (2000) The New Deal Handook, Unemployment Unit and Youthaid, London.

De Koning J., Denys J. \& Walwei U. (1999) Deregulation in Placement Services: a comparative study for eight countries, DGV, European Commission, Brussels.

DfEE (2000a) Action Teams for Jobs, Department for Education and Employment, London.

DfEE (2000b) New Deal for Young People and Long-Term Unemployed People aged 25+, Statistics to July 2000, SFR 38/2000, 28 September, DfEE, London.

DfEE (2000c) New Deal for Lone Parents, Statistics to July 2000, SFR 41/2000, 5 October, DfEE, London.

ESC and SSC (1999) The One Service Pilots: The Government's Response to the sixth report of the Education and Employment Committee and the seventh report of the Social Security Committee of session 1998-99, HC 855, The Stationery Office, London.

Finn D., Blackmore M. and Nimmo M. (1998) Welfare to Work and the Long Term

Unemployed: They're very cynical, Unemployment Unit and Youthaid, London.

Finn D. (2000) 'Welfare to Work: the local dimension', in Journal of European

Social

Policy, Vol. 10, No. 1, pp 43-57, Sage Publications, London.

Gregg P. \& Wadsworth J. (1997) 'A Year in the Labour market', Employment Audit, Issue 4, Summer, Employment Policy Institute, London.

Hasluck C. (2000a) The New Deal for Young People: Two Years On, ESR 41, Employment Service Research and Development Branch, Sheffield.

Hasluck C. (2000b) Early Lessons from the Evaluation of the New Deal Programmes, ESR 49, Employment Service Research and Development Branch, Sheffield.

Hasluck C., McKnight A. and Elias P. (2000) Evaluation of the New Deal for Lone Parents: Early lessons from the Phase One Prototype - Cost-benefit and Econometric Analyses, Department of Social Security Research Report No. 110, London.

Hirsch D. (2000) 'Say thank you to Mr. Brown', New Statesman, London, pp 36-37.

HMSO (1998a) New ambitions for our country: A new contract for welfare, HMSO, Cm 3805, London.

HMSO (1998b) A new contract for welfare: The Gateway to Work, HMSO, Cm 4102, London.

HMSO (1999) Opportunity for All: Tackling Poverty and Social Exclusion, Cm 4445, 
London.

Jessop B. (1994) 'Post-Fordism and the state', in Post Fordism: A Reader, (ed) Amin A., Blackwell, Oxford.

Laarson A. (1998) From Welfare to Work, UK Presidency Conference, $23^{\text {rd }}$ June, Newcastle,

Layard R. (2000) 'Welfare to work and the New Deal', World Economics, Vol. 1, No. 2, London.

Le Grand J. and Bartlett W. (eds) (1993) Quasi-Markets and Social Policy,

Macmillan

Press, Houndmills.

Lipsky, M. (1980) Street-Level Bureaucracy: Dilemmas of the Individual in Public Services, Russell Sage Foundation, New York.

LMT (1996) Labour Market Trends, October, Office for National Statistics, London.

Martin J. (1998) What works among active labour market policies: evidence from OECD Countries' experiences, OECD Occasional Papers, Paris.

McKay S., Walker R. \& Youngs R. (1997) Unemployment and Jobseeking before Jobseeker's Allowance, DSS Research Report No. 73, London.

Millar J. (2000) Keeping track of welfare reform: The New Deal programmes, Rowntree Foundation, York Publishing Services.

Milliband D. (1999) This is the Modern World, Fabian Review, vol 111, No. 4, London.

NDTF (1999) Lasting Value: Recommendations for Increasing Retention within the New Deal, New Deal Task Force, DfEE, London.

NCSR (1999) Unknown Destinations in the New Deal, unpublished report, National Centre for Social Research.

OECD (1994) The OECD Jobs Study: Evidence and Explanation, Organisation for Economic Cooperation and Development, Paris.

ONS (2000) Labour Market Statistics July 2000: First Release, 12 July, Office for National Statistics, London

Payne J., Lissenburgh S., White M. and Payne C. (1996) Employment Training and Employment Action: An evaluation by the matched comparison method, Research Series No.74, DfEE, London.

Piachaud D. and Sutherland H. (2000) How Effective is the British Government's Attempt to reduce Child Poverty?, CASE Paper No. 38, Centre for the Analysis of Social Exclusion, London School of Economics, London.

Peck J. and Jones M. (1995) 'Training and Enterprise Councils: Schumpterian workfare state, or what?, Environment and Planning A 27.

Peck J. (1999) New Labourers? Making a New Deal for the 'workless class', Environment and Planning C, Government and Policy, vol. 17.

Peck J. and Theodore N. (1999) Beyond 'employability', paper presented to the Conference on Social Justice and Economic Efficiency, 12-13 April, Cambridge.

PM (1997) Speech by the Prime Minister the Rt Hon Tony Blair MP at the Aylesbury Estate, Southwark, on Monday 2 June, London.

Ramia G. and Carney T. (1999) Managerialism and Welfare: the Australian Experiment with a Marketised Employment Services Network, paper presented at the $32^{\text {nd }}$ Social Policy Association Conference, Roehampton Insitute, London, 20-22 July. 
R\&DDES (2000) What Works: Evidence from New Deal for Young People, Research and Development Branch of the Employment Service, unpublished paper given at the UK/US Symposium on Welfare to Work: New Solutions for the New Economy, 20-21 July, Windsor.

Tonge J. (1999) 'New packaging, old deal? New labour and employment policy innovation', in Critical Social Policy, vol. 19, no. 2, Sage, London.

Turok I. and Webster D. (1998) The New Deal: Jeopardised by the geography of unemployment?, in Local Economy, vol. 12, no. 4, Pitman, London.

Turok I. and Edge N. (1999) The Jobs Gap in Britain's Cities: Employment loss and labour market consequences, Joseph Rowntree Foundation, Policy Press, Bristol.

White, M., Lissenburgh, S. and Bryson, A. (1997) The Impact of Public Job Placing Programmes, Policy Studies Institute, London. 